\title{
Dredging impact on the benthic community of an unaltered inlet in southern Spain
}

Received: 29 November 2002 / Revised: 15 September 2003 / Accepted: 15 September 2003 / Published online: 15 November 2003 (C) Springer-Verlag and AWI 2003

\begin{abstract}
The impact of dredging on macrobenthic communities was studied in an unaltered zone, the Getares inlet of Algeciras Bay (SW Spain). The data obtained before, during and after dredging in a time series spanning 5 years revealed the re-establishment of directly affected communities and of physicochemical substrate characteristics within 1 month of the end of dredging, although 2 years later there was a confusing biological impoverishment of the whole inlet. After 4 years, there was a high degree of population re-establishment, both on the bottoms directly affected by the works and on neighbouring areas, that was partly due to the hydrodynamic conditions. Before this type of activity is undertaken, each case should be studied regarding viability, the environmental medium where it will take place, the best time of year, and the type of dredging to be used.
\end{abstract}

Keywords Macrobenthos - Sediment - Dredging impact . Southern Spain

\section{Introduction}

The coast of Algeciras Bay, located in the easternmost zone of the Strait of Gibraltar, is environmentally diverse despite its relatively limited extent (approximately $30 \mathrm{~km}$ in length and $8 \mathrm{~km}$ in width at the mouth). This is mainly due to the natural topography and intensive industrial activities over the past 30 years, which have resulted in the construction of sea walls, breakwaters and landfills.

Communicated by H.-D. Franke

J. E. Sánchez-Moyano (®) · F. J. Estacio · E. M. García-Adiego ·

J. C. García-Gómez

Laboratorio de Biología Marina,

Dpto. Fisiología y Biología Animal,

Facultad de Biología, Universidad de Sevilla,

Avd. Reina Mercedes 6, 41012 Seville, Spain

e-mail: smoyano@us.es

Tel.: +34-954-557100

Fax: +34-954-233480
The effects of human activities on the coastal fauna of Algeciras Bay have been demonstrated previously by diverse studies on the distribution of the algal epifauna, soft-bottom communities and special animal groups such as sponges and ascidians (Carballo et al. 1994, 1996; Naranjo et al. 1996; Estacio et al. 1997; Sánchez-Moyano and García-Gómez 1998; Sánchez-Moyano et al. 2000a, 2000b, 2002; Carballo and Naranjo 2002). These studies indicated a good environmental quality in the outermost areas of the bay, especially at Getares Inlet, but also revealed certain conditions which restrict the occurrence of organisms in the interior part.

From March to June 1993 the Getares inlet was subjected to dredging works in a strip running between 15 and $30 \mathrm{~m}$ in depth. A total of 2 million $\mathrm{m}^{3}$ of sediment was extracted using a trailer suction hopper dredging to landfills at Port of Algeciras. The removal of sediment and fauna, and the re-suspension and re-deposition of the finest material extracted, resulted in various alterations to the bottoms directly affected, as well as to the fauna of neighbouring rocky substrates. The effects of dredging on marine organisms and the recolonization of disturbed areas can be very diverse, and have been studied repeatedly (McCall 1977; Rosenberg 1977; López-Jamar and Mejuto 1988; Defeo 1996; Kenny and Rees 1996; Newell et al. 1998; Pranovi et al. 1998; van Dalfsen et al. 2000; Sardá et al. 2000). The above method of dredging is the one most used on European coasts and its physical impacts relate to substrate removal, alteration of bottom topography, overflows into the water column and redeposition of material (De Groot 1996).

Since Getares Inlet was not altered in any other way by human activities during the study period, an analysis of the communities in the affected zone and neighbouring areas before, during and over a 5-year period after the works, offered an opportunity to study the degree and timing of recovery of affected populations.

Furthermore, the study intended to clarify some points that should be considered before dredging works are carried out. 
Fig. 1 Location of Getares Inlet, dredging area, and sampling stations $(G 1, G 2, G 3)$

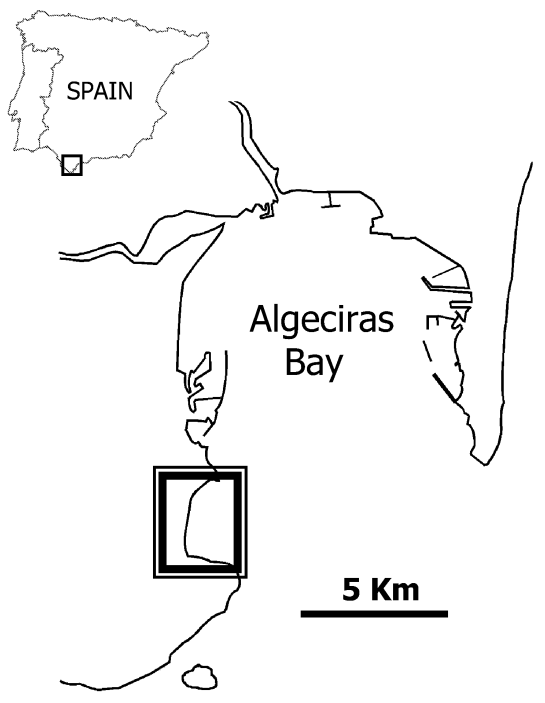

\section{Methods}

Three stations were selected at 5, 15 and $30 \mathrm{~m}$ depth (G1, G2 and G3, respectively) (Fig. 1). Only station G3 was directly affected by dredging. At the neighbouring stations $\mathrm{G} 1$ and $\mathrm{G} 2$, communities could undergo their natural fluctuations in time. No samples from a control area were available due to the lack of a nearby suitable reference site with characteristics similar to G3.

The study began in October 1992, i.e. before dredging works (March to June 1993) were started; the results obtained in that month were used as control. The next sampling was in March 1993, i.e. during the works. In that same year, samples were also taken in July and October, i.e. 1 and 4 months, respectively, after the works had ended. Two years later (1995), samples were taken in March, July and October. Further samplings were done in April and October 1997 and in October 1998.

Samples were taken with a $0.05-\mathrm{m}^{2}$ van Veen grab. Five samples were sufficient to estimate the total diversity. They were sieved through a $0.5-\mathrm{mm}$ mesh (Lewis and Stoner 1981). Infauna samples were preserved in $5 \%$ buffered formaldehyde containing Rose Bengal solution as a staining agent to facilitate sorting of the organisms. The macrofauna was identified at least to family level. Identification of animals to taxonomic levels equal to or even higher than family has been used in many studies on changes in marine environments (Herman and Heip 1988; Ferraro and Cole 1990, 1995; Warwick and Clarke 1991; Vanderklift et al. 1996; Pagola-Carte et al. 2001) and has been found to be sufficient to determine the effects of dredging on the composition of the benthic macrofauna (Harvey et al. 1998; De Grave and Whitaker 1999). This approach reduces the number of rare taxa and minimises the problems with the analysis of data matrices containing large numbers of zeroes (Legendre and Legendre 1998).

The data (sum of five samples) were analysed to obtain the total number of taxa, total abundance and diversity according to the Shannon-Weaver Index (Shannon and Weaver 1963) using neperian logarithms. Spatial and temporal differences in these community parameters were analysed by one-way ANOVA, after verifying normality (Kolmogorov-Smirnov test) and homogeneity of variances (Barlett test). Homogenous groups were separated by a Tukey test.

Affinities between stations were established using MDS (nonmetric multidimensional scaling) analysis with the taxa abundance (transformed by the fourth root). The differences in community composition were tested with the non-parametric ANOSIM test from PRIMER package (Clarke and Green 1988).

One sample was taken for sediment analysis at each station and period using a van Veen grab (granulometry and organic matter percentage). The granulometric analyses followed the method proposed in Guitian and Carballas (1976). The percentage of organic matter in the sediment was obtained as weight loss by ignition at $500^{\circ} \mathrm{C}$ for $4 \mathrm{~h}$.

\section{Results}

Sediment analysis

Table 1 shows the results of sediment analyses. In general, the sediment of the Getares Inlet bottoms was composed of fine sands with a moderately good selection.

The results obtained before, during and after dredging works revealed no significant changes in the type of sediment and its organic content at the three stations (Table 1). Only in 1997 and 1998 was there an increase in the proportion of coarse sand at the three stations compared with previous years. Silt and clay percentages at station G3, however, changed significantly. From $0.73 \%$ before dredging started, it increased to $8.93 \%$ (July 1993) and $11.57 \%$ (October 1993) immediately after the end of the dredging works. This was probably due to resuspension and re-deposition of the overflow. Afterwards, the silt-clay percentage returned to values similar to those recorded before the start of dredging.

The organic content could not be considered high from the granulometric characteristics of the substrate (Table 1). Its increase with depth followed the normal trend in coastal systems unaffected by waste disposal.

\section{Macrobenthic communities}

A total of 137 taxa were recorded in the study area over the sampling period. These taxa comprise 37 polychaete families, 45 mollusc families, 40 crustacean families, five echinoderm families and ten belonging to other groups. The most abundant taxa, among others, were the mollusc 
Table 1 Percentages of coarse elements, sands, silt-clays and organic matter, and type of sediment and selection for each station and sampling period

\begin{tabular}{|c|c|c|c|c|c|c|c|}
\hline Period & Station & $\begin{array}{l}\text { Coarse elements } \\
(\%)\end{array}$ & $\begin{array}{l}\text { Sand } \\
(\%)\end{array}$ & $\begin{array}{l}\text { Silt-clays } \\
(\%)\end{array}$ & $\begin{array}{l}\text { Sediment } \\
\text { type }\end{array}$ & Sorting & $\begin{array}{l}\text { Organic. mMatter } \\
(\%)\end{array}$ \\
\hline October 1992 & $\begin{array}{l}\text { G1 } \\
\text { G2 } \\
\text { G3 }\end{array}$ & $\begin{array}{l}0.61 \\
0.97 \\
0.69\end{array}$ & $\begin{array}{l}97.54 \\
96.98 \\
98.58\end{array}$ & $\begin{array}{l}1.85 \\
2.05 \\
0.73\end{array}$ & $\begin{array}{l}\text { Fine sand } \\
\text { Fine sand } \\
\text { Fine sand }\end{array}$ & $\begin{array}{l}\text { Mod. well sorted } \\
\text { Mod. well sorted } \\
\text { Mod. well sorted }\end{array}$ & $\begin{array}{l}2.69 \\
2.57 \\
3.42\end{array}$ \\
\hline March 1993 & $\begin{array}{l}\text { G1 } \\
\text { G2 } \\
\text { G3 }\end{array}$ & $\begin{array}{r}0.42 \\
0.09 \\
-\end{array}$ & $\begin{array}{l}98.73 \\
97.13 \\
-\end{array}$ & $\begin{array}{r}0.85 \\
2.78 \\
-\end{array}$ & $\begin{array}{l}\text { Fine sand } \\
\text { Fine sand } \\
\text { - }\end{array}$ & $\begin{array}{l}\text { Moderately sorted } \\
\text { Mod. well sorted } \\
\text { - }\end{array}$ & $\begin{array}{l}1.8 \\
3.06 \\
-\end{array}$ \\
\hline July 1993 & $\begin{array}{l}\text { G1 } \\
\text { G2 } \\
\text { G3 }\end{array}$ & $\begin{array}{l}0.75 \\
0.15 \\
0.97\end{array}$ & $\begin{array}{l}99.12 \\
97.54 \\
90.1\end{array}$ & $\begin{array}{l}0.13 \\
2.31 \\
8.93\end{array}$ & $\begin{array}{l}\text { Fine sand } \\
\text { Fine sand } \\
\text { Fine sand }\end{array}$ & $\begin{array}{l}\text { Mod. well sorted } \\
\text { Mod. well sorted } \\
\text { Moderately sorted }\end{array}$ & $\begin{array}{l}1.53 \\
1.8 \\
2.63\end{array}$ \\
\hline October 1993 & $\begin{array}{l}\text { G1 } \\
\text { G2 } \\
\text { G3 }\end{array}$ & $\begin{array}{l}0.8 \\
0.2 \\
0.5\end{array}$ & $\begin{array}{l}95.92 \\
97.08 \\
87.93\end{array}$ & $\begin{array}{r}3.28 \\
2.72 \\
11.57\end{array}$ & $\begin{array}{l}\text { Fine sand } \\
\text { Fine sand } \\
\text { Fine sand }\end{array}$ & $\begin{array}{l}\text { Mod. well sorted } \\
\text { Mod. well sorted } \\
\text { Moderately sorted }\end{array}$ & $\begin{array}{l}1.7 \\
1.5 \\
2.52\end{array}$ \\
\hline March 1995 & $\begin{array}{l}\text { G1 } \\
\text { G2 } \\
\text { G3 }\end{array}$ & $\begin{array}{l}1.88 \\
0.5 \\
1.45\end{array}$ & $\begin{array}{l}97.96 \\
92.75 \\
92.83\end{array}$ & $\begin{array}{l}0.16 \\
1.98 \\
5.72\end{array}$ & $\begin{array}{l}\text { Fine sand } \\
\text { Fine sand } \\
\text { Fine sand }\end{array}$ & $\begin{array}{l}\text { Mod. well sorted } \\
\text { Mod. well sorted } \\
\text { Moderately sorted }\end{array}$ & $\begin{array}{l}1.46 \\
2.82 \\
3.44\end{array}$ \\
\hline July 1995 & $\begin{array}{l}\text { G1 } \\
\text { G2 } \\
\text { G3 }\end{array}$ & $\begin{array}{l}0.36 \\
0.4 \\
0.72\end{array}$ & $\begin{array}{l}99.04 \\
96.82 \\
94.01\end{array}$ & $\begin{array}{l}0.6 \\
2.78 \\
5.27\end{array}$ & $\begin{array}{l}\text { Fine sand } \\
\text { Fine sand } \\
\text { Fine sand }\end{array}$ & $\begin{array}{l}\text { Mod. well sorted } \\
\text { Moderately sorted } \\
\text { Moderately sorted }\end{array}$ & $\begin{array}{l}2.5 \\
1.87 \\
3.56\end{array}$ \\
\hline October 1995 & $\begin{array}{l}\text { G1 } \\
\text { G2 } \\
\text { G3 }\end{array}$ & $\begin{array}{l}0.80 \\
0.39 \\
0.87\end{array}$ & $\begin{array}{l}98.05 \\
96.38 \\
92.69\end{array}$ & $\begin{array}{l}1.15 \\
2.44 \\
6.44\end{array}$ & $\begin{array}{l}\text { Fine sand } \\
\text { Fine sand } \\
\text { Fine sand }\end{array}$ & $\begin{array}{l}\text { Mod. well sorted } \\
\text { Moderately sorted } \\
\text { Moderately sorted }\end{array}$ & $\begin{array}{l}1.95 \\
2.27 \\
3.11\end{array}$ \\
\hline April 1997 & $\begin{array}{l}\text { G1 } \\
\text { G2 } \\
\text { G3 }\end{array}$ & $\begin{array}{l}2.79 \\
0.77 \\
3.32\end{array}$ & $\begin{array}{l}95.16 \\
97.9 \\
96.68\end{array}$ & $\begin{array}{l}2.05 \\
1.33 \\
0\end{array}$ & $\begin{array}{l}\text { Fine sand } \\
\text { Fine sand } \\
\text { Fine sand }\end{array}$ & $\begin{array}{l}\text { Mod. well sorted } \\
\text { Mod. well sorted } \\
\text { Moderately sorted }\end{array}$ & $\begin{array}{l}1.03 \\
1.33 \\
2.32\end{array}$ \\
\hline October 1997 & $\begin{array}{l}\text { G1 } \\
\text { G2 } \\
\text { G3 }\end{array}$ & $\begin{array}{l}4.44 \\
6.29 \\
4.44\end{array}$ & $\begin{array}{l}93.61 \\
92.78 \\
93.61\end{array}$ & $\begin{array}{l}1.95 \\
0.93 \\
1.95\end{array}$ & $\begin{array}{l}\text { Fine sand } \\
\text { Fine sand } \\
\text { Fine sand }\end{array}$ & $\begin{array}{l}\text { Moderately sorted } \\
\text { Moderately sorted } \\
\text { Moderately sorted }\end{array}$ & $\begin{array}{l}1.86 \\
1.65 \\
3.28\end{array}$ \\
\hline October 1998 & $\begin{array}{l}\text { G1 } \\
\text { G2 } \\
\text { G3 }\end{array}$ & $\begin{array}{r}17.23 \\
33.85 \\
4.17\end{array}$ & $\begin{array}{l}81.72 \\
61.39 \\
94.43\end{array}$ & $\begin{array}{l}1.05 \\
4.76 \\
1.4\end{array}$ & $\begin{array}{l}\text { Fine sand } \\
\text { Fine sand } \\
\text { Fine sand }\end{array}$ & $\begin{array}{l}\text { Moderately sorted } \\
\text { Poorly sorted } \\
\text { Moderately sorted }\end{array}$ & $\begin{array}{l}1.92 \\
2.13 \\
3.00\end{array}$ \\
\hline
\end{tabular}

families Venereidae, Semelidae and Tellinidae; the crustacean family Apseudidae; the echinoderm family Amphiuridae; and the polychaete families Spionidae and Onuphidae (Table 2).

The taxon numbers at stations G1 and G2 followed the natural fluctuations in time, with a maximum in autumn, a minimum in winter, and reestablishment over the summer (Fig. 2). At G3, however, the taxon number decreased statistically during the dredging period (March 1993), remained low in 1995, and then recovered (Fig. 2; Table 3).

Abundance values during the first year of the study (1992-1993) showed different trends at the three stations. At stations G1 and G2, there was no relationship with dredging, although the values decreased significantly in 1995 and in March 1997. At station G3, there was a low abundance during dredging in March 1993, and during 1995, whereas in other periods the values did not differ significantly from those recorded before dredging in October 1992 (Fig. 2; Table 3). The general decrease in abundance values during 1995 at all three stations was noticeable.

Similarly, the Shannon-Weaver diversity index at G1 and G2 did not show any relationship with the dredging works, but followed the natural fluctuations over the sampling period (Fig. 2). At station G3, a similar trend was observed, yet the index decreased significantly during dredging works (March 1993), recovered in July and October 1993, decreased again in 1995 and was reestablished in October 1997 and 1998 (no significant differences to values obtained before dredging in October 1992) (Fig. 2; Table 3).

Multivariate analysis

Through the MDS analysis of all stations and periods (Fig. 3) we obtained a clear separation between station G3 in March 1993 (during dredging) and all other stations and periods. Furthermore, the 1995 samplings coinciding with a critical period in the whole inlet were clearly different from others. Ultimately, an MDS analysis for stations only showed a clear change in the macrobenthic communities along a depth gradient, except station G3 in March 1993.

An MDS analysis of the abundance in each period at station G3, the only station directly affected by the dredging works, showed three groupings (Fig. 4): one comprising the periods of March, July and October 1995 (period more or less unfavourable in the whole inlet); a 


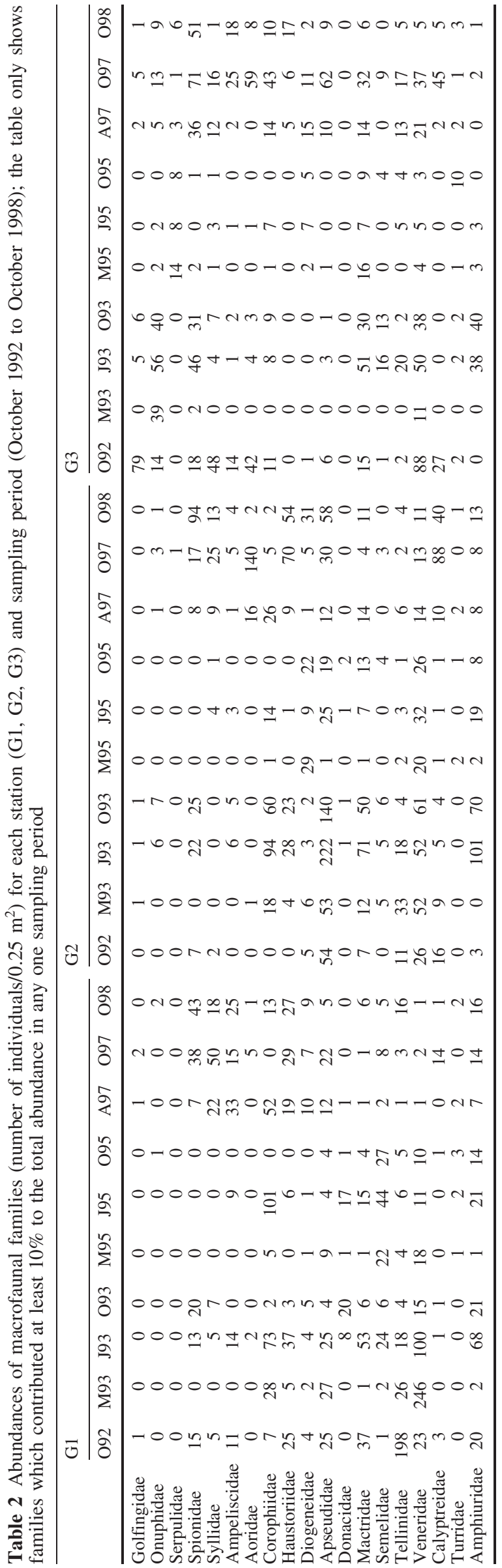

second grouping comprising October 1992, July and October 1993, April and October 1997, and October 1998 (control sampling, post-dredging period, and the last 2 years); and, finally, March 1993, representing a third grouping clearly different from the others.

In general, there were certain similarities between the first and the last 2 years in the whole inlet. At station G3, the similarities between October 1992 and later periods were $60 \%$ for October 1993, 64\% for October 1997, and $48 \%$ for October 1998. The greatest differences between October 1992 and later periods were recorded in 1995 and, in the case of station G3, in March 1993.

The differences in community composition at station G3 were tested using the non-parametric ANOSIM test. According to this test, the community composition in March 1993 was significantly different from the rest $(P<0.01)$, except for July 1995. Neither were there significant differences among 1995 samplings $(P>0.2)$. Even though the control sampling (October 1992) showed significant differences compared to post-dredging samplings $(P<0.01)$, the $R$ statistic values are low (e.g. 0.324 for October 1993, 0.54 for March 1997, and 0.56 for October 1997) which indicates a certain similarity in the community composition throughout the study period, except for October $1998(R=0.9)$.

This is also indicated by the number and percentage of the common taxa present at each station and period compared with the period before dredging (Table 4). At stations G1 and G2, the percentage of common taxa present during the study with respect to those present before dredging was high (e.g. G1: 84.8\% in July 1993 and $72.7 \%$ in October 1997; G2: 68.9\% in July 1993, and $72.4 \%$ in October 1998). However, at station G3 we observed more notable changes. Thus, by March 1993 many of the common taxa present at this station before dredging had disappeared (only $8.4 \%$ of the taxa present in 1992 were detected) but, by July and October 1993, $52.1 \%$ and $54.9 \%$, respectively, had recovered. In 1995, there was again a disappearance of organisms: October 1997 showed the maximum recovery of taxa $(67.6 \%)$, but the percentage decreased again to 46.4\% in October 1998 (Table 4).

\section{Discussion}

The dredging during 1993 generated a marked impoverishment of the macrobenthic community of the sediment in the directly affected zone during the works. However, 1 month after the works had finished, the community was largely re-established. This achievement was stable by the fourth year after the end of the works. The sedimentary bottoms close to the dredging area were not significantly affected during the works, possibly due to the tidal regime from the Strait of Gibraltar which directs the possible overflow away from the shallower areas because of the current parallel to the coast.

The environmental impacts of dredging or deposition of rejected material are mainly confined to a radius of a 


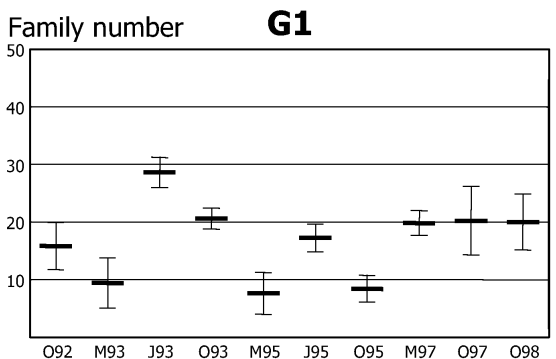

Abundance

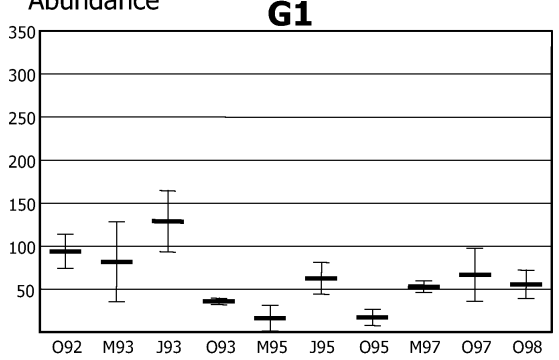

Diversity

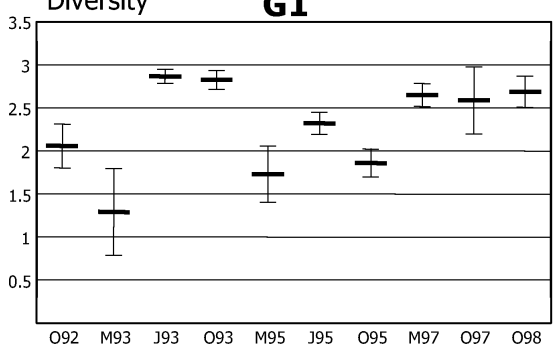

G2

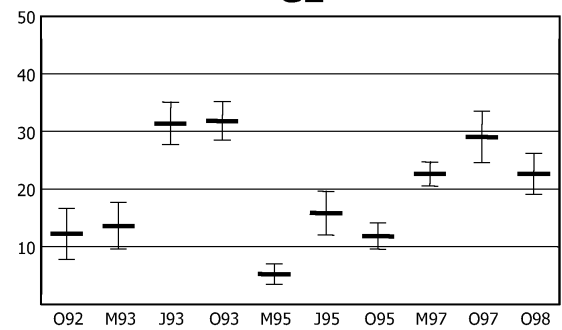

G2

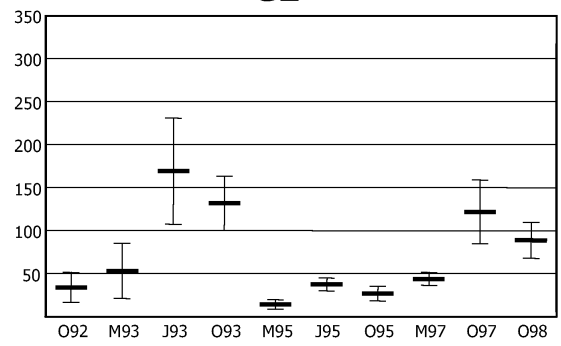

G2

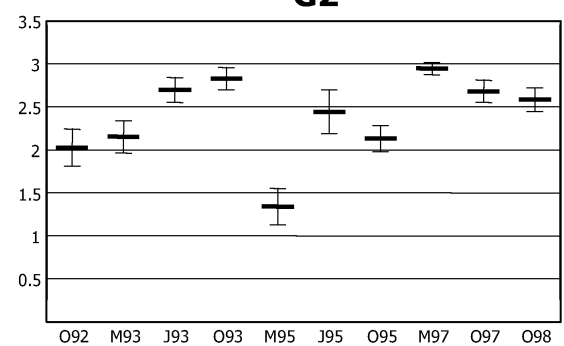

G3

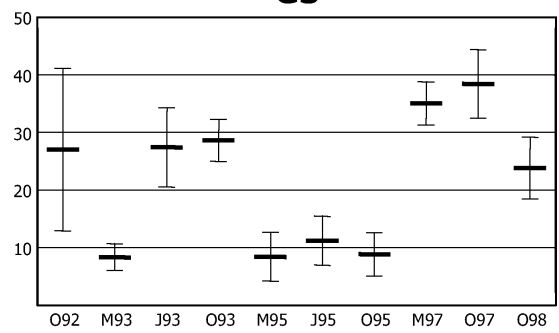

G3

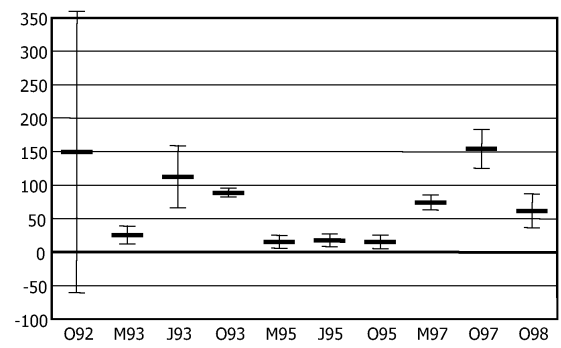

G3

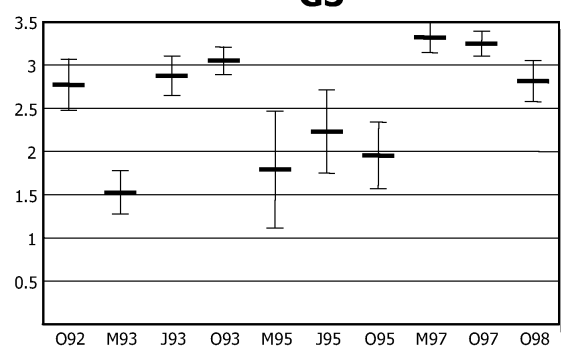

Fig. 2 Total number of family taxa, number of individuals, and diversity (Shannon-Weaver) for each station (G1, G2, G3) and sampling period (calculated from pooled samples, $n=5$ ). Horizontal
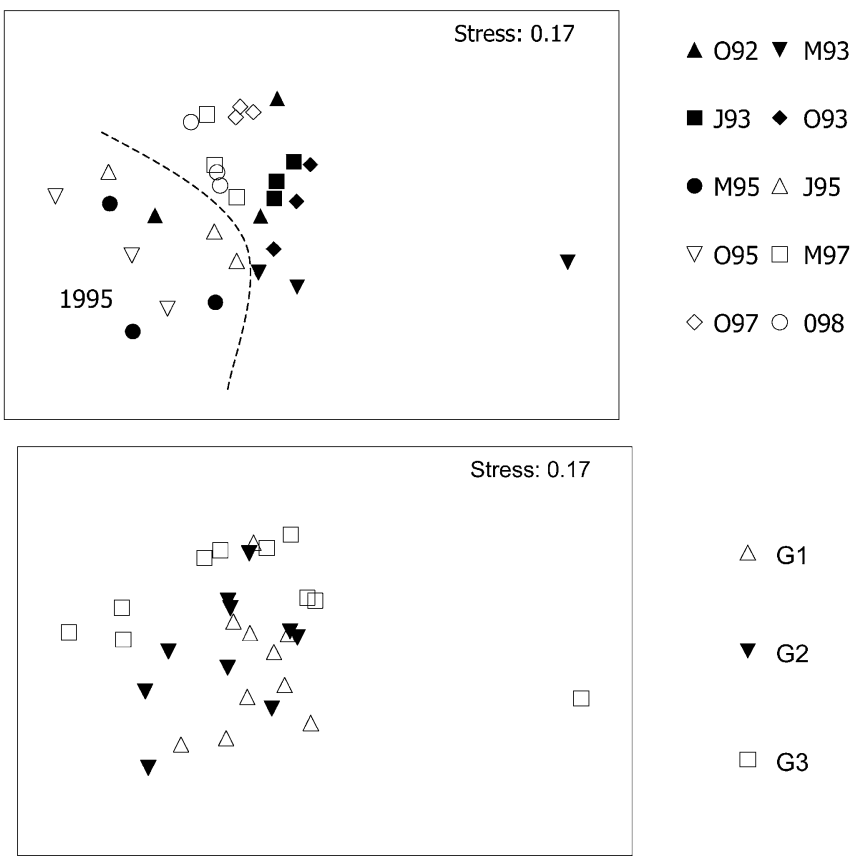

$\triangle \mathrm{G} 1$

$\square \mathrm{G} 3$

and vertical lines indicate means and standard deviations, respectively

Fig. 3 MDS ordination for all stations and sampling periods

few hundred metres (Newell et al. 1998) or may even remain restricted to the dredging area (Lewis et al. 2001).

The main physical impacts of dredging activities relate to removal of sedimentary material, alteration of bottom topography and re-deposition of sediment, both in the directly affected zone and in neighbouring areas depending on several factors, such as extraction method, granulometric characteristics and current strength (McCall 1977; Rosenberg 1977; De Groot 1996; Newell et al. 1998; Desprez 2000).

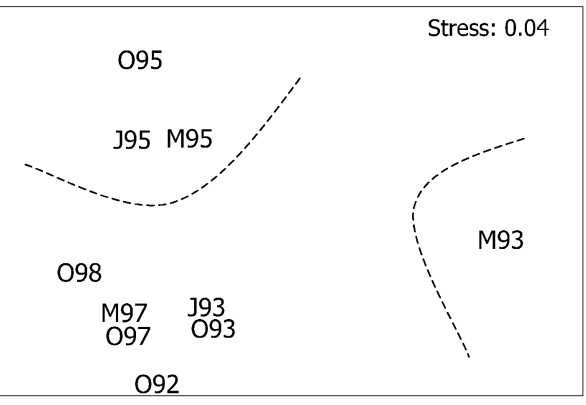

Fig. 4 MDS ordination for the sampling periods at station G3 
Table 3 Results of the one-way ANOVA for the univariate parameters at each station. Df: degree of freedom; $M S$ : mean squarer; $F$ : statistics; $* P<0.001 ;$ n.s. not significant. The homogenous groups according to the Tukey test $(P<0.05)$ are indicated by a continuous line

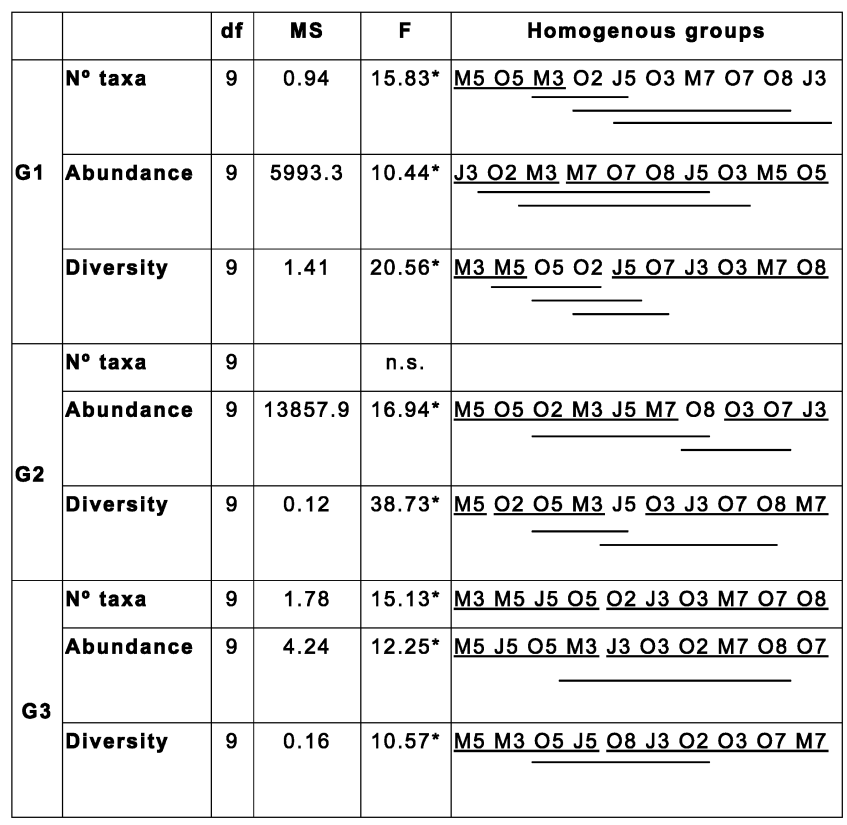

Changes in the physicochemical characteristics of the sediment, especially granulometric composition and organic content, cause marked initial alterations in populations (López-Jamar and Mejuto 1988), and may subsequently change the community composition (McCall 1977; Bonsdorff 1983; van Dalfsen et al. 2000).

In our study, no changes in sediment type or organic content were evident. However, we found differences in community composition. According to Snelgrove and Butman (1994) and Newell et al. (1998), it seems that communities are controlled by interactions of physical and biological factors at the sediment-water interface, operating over long time periods, rather than by granulometry. Nevertheless, granulometry can directly affect any species which has specific sediment type requirements (Seiderer and Newell 1999; Newell et al. 2001).

Direct short-term effects of dredging on macrofauna communities are usually a fall in the number of taxa, abundance and biomass (Newell et al. 1998). The capacity of the system to re-establish is very variable and depends, among other factors, on the community type of the affected and nearby areas, on local hydrological and sedimentological conditions (van Dalfsen et al. 2000), on the season when dredging is carried out, on its intensity and penetration into the substrate (Kaiser and Spencer 1996; Pranovi et al. 1998), on the lifecycles and feeding strategies of the species (López-Jamar and Mejuto 1988), and on settlement of larvae and immigration of mobile species (Hall 1994; Defeo 1996).

The initial recovery is usually rapid and involves opportunistic species, but it may take 5 years or more for a community to reach "maturity" (Desprez 2000). For instance, bottom communities in the port of La Coruña (López-Jamar et al. 1995) showed an initial recovery within 6 months of the end of dredging activities and stabilised by the third or fourth year. Kenny and Rees (1994, 1996) reported that, although there was some recolonization within 7 months, the community composition was not restored even 2 years after dredging. On the other hand, Newell et al. (1998) suggested a recovery time of 6-8 months for communities in unstable environments such as estuaries and muddy bottoms; $2-3$ years for communities of sand and gravels; and 5-10 years for more complex biological associations such as mäerl bottoms.

In this study, dredging impacts on communities remained concentrated in the working area and the period when the works were carried out, and no significant changes occurred in neighbouring sedimentary bottoms. There was a rapid re-establishment of populations within 1 month of the end of dredging activities. This was partly because the season was favourable for the settlement of planktonic larvae produced during spring, and partly because of optimal hydrodynamic conditions in the affected area (Carballo et al. 1996). The importance of hydrodynamic conditions has been stated by van Dalfsen et al. (2000): in highly dynamic systems, such as the North Sea, there are minor community changes and the recovery is rapid, whereas in more stable environments, such as the Mediterranean coasts, changes are more evident and may last much longer. According to van Dalfsen et al. (2000), the recovery of a system can also occur through rapid colonization from "refuge areas", especially from unaltered tracks which are usually left over with the common method of dredging.

Most studies demonstrated a first phase of recolonization of the substrate by opportunistic species, with an initial rise in abundance in the defaunated area after dredging and with low densities later in the presence of other species (McCall 1977; López-Jamar et al. 1995).

Table 4 Number and percentage of common taxa recorded for each station (G1, G2, G3) and sampling period, compared with October 1992

\begin{tabular}{|c|c|c|c|c|c|c|c|c|c|c|c|c|c|}
\hline & \multirow{2}{*}{$\begin{array}{l}\text { October } 1992 \\
\text { Number } \\
\text { of Families }\end{array}$} & \multicolumn{2}{|l|}{ March 1993} & \multicolumn{2}{|l|}{ July 1993} & \multicolumn{2}{|c|}{ October 1993} & \multicolumn{2}{|c|}{ October 1995} & \multicolumn{2}{|c|}{ October 1997} & \multicolumn{2}{|c|}{ October 1998} \\
\hline & & $\overline{\text { Common }}$ & New & Common & $\overline{\mathrm{New}}$ & $\overline{\text { Common }}$ & $\overline{\text { New }}$ & Common & $\overline{\text { New }}$ & Common & $\overline{\text { New }}$ & Common & New \\
\hline$\overline{\mathrm{G} 1}$ & 33 & 17 & 10 & & 22 & & 16 & & 10 & & 1 & & 15 \\
\hline G3 & 71 & $6(8.4 \%)$ & 5 & $37(52.1 \%)$ & 8 & $39(54.9 \%)$ & 11 & $18(25.6 \%)$ & 5 & $48(67.6 \%)$ & 19 & $33(46.4 \%)$ & 24 \\
\hline
\end{tabular}


However, in our study the populations present 1 month after the works had ended were not dominated by opportunistic taxa, or by other taxa not representative of the community. Probably a normal larval recruitment could occur on these bottoms after dredging activities had ended, or the phase of opportunistic recolonization was very short and remained undetected.

The organisms which were missing after dredging belonged to families that were of low abundance or rare before dredging. This was also observed by Kenny and Rees (1996) who concluded that dominant or representative species can rapidly colonize the affected sediment, while others cannot.

Despite having recovered 52.1\% (July 1993), 54.9\% (October 1993) and 67\% (1997) of the taxa present in 1992, including the most characteristic and most abundant taxa, the communities showed changes in the density of certain of these taxa compared with 1992. For instance, there was a general decrease in the family Veneridae compared with 1992-1993, and fluctuations throughout the study of other representative families, such as the Tellinidae, Mactridae and Amphiuridae.

The recovery of the community does not necessarily lead to the original situation, because natural fluctuations are normal in the coastal zone (van Dalfsen et al. 2000). Benthic soft-bottom communities usually show long-term variations due to seasonal patterns in reproduction (López-Jamar et al. 1986) and because of variable environmental factors related to larval dispersal and recruitment (Defeo 1996), predation and competition (Thorson 1966). So, "re-establishment" is difficult to define since community composition can vary over time even in undisturbed areas (Seiderer and Newell 1999). For instance, Kenny et al. (1998) showed that changes in a community occurred in both dredging and control zones in such a way that both zones were similar to each other 3 years after perturbation but different from the original community.

The confusing results obtained in 1995 in the whole inlet might be explained by various hypotheses: an increase in the discharge of urban wastes and worksgenerated material into the marine environment as a result of the strong urban growth on the inlet coast; a reorganization of the mobile sedimentary material in the inlet (and thereby the fauna) to balance the affected zone; and, lastly, biological aspects related with larval release, dispersion and recruitment on these bottoms. LópezJamar and Mejuto (1988) detected a biological impoverishment after a significant initial population increase following dredging; such effects, however, reflected in a decrease in the values of diversity, were caused by the dominance of certain species and not by a real decrease in biological richness.

To avoid serious impacts of dredging on the benthic fauna, certain aspects must be taken into consideration. The type of dredging employed can affect the time course of recolonization. Because most of the macrobenthos lives in the top $30 \mathrm{~cm}$ of the sediment, the number of animals removed is directly related to the surface area of extraction (van Dalfsen et al. 2000). Pranovi et al. (1998) demonstrated that, with dredging that penetrates only 7 $13 \mathrm{~cm}$ into the sediment, the fauna can recover after 15 days, but if the penetration is $20 \mathrm{~cm}$, recovery does not start until after 60 days, depending on whether the organisms live on the surface of the sediment or in deeper zones. Re-suspension of fine sedimentary materials must be avoided. This is particularly important for bottoms which consist mainly of fine materials, as their subsequent sedimentation can have serious impacts, especially on neighbouring rocky substrates with their highly fragile sessile fauna. Thus, the type of dredging to be used should be selected depending on the sediment type.

The seasonal timing of dredging activities is crucial as their impacts can be minimal or disastrous depending on time. Periods related to reproduction or larval recruitment (usually the warmest months) should be avoided. The least harmful season will usually be the winter months. Consequently, the dredging activities for landfills or beach nourishment should be appropriately controlled in each case, in order to minimize their impacts on softbottom biotic communities.

Acknowledgements We wish to thank the Autoridad Portuaria de la Bahía de Algeciras (APBA) for financial support of this study.

\section{References}

Bonsdorff E (1983) Recovery potential of macrozoobenthos from dredging in shallow brackish waters. In: Cabioch L, Glémarec M, Samains JF (eds.) Fluctuation and succession in marine ecosystems. Proceedings of the 17th European Marine Biology Symposium, Brest (France). Oceanol Acta (special issue):2732

Carballo JL, Naranjo SA (2002) Environmental assessment of a large industrial marine complex based on a community of benthic filter-feeders. Mar Pollut Bull 44:605-610

Carballo JL, Sánchez-Moyano JE, García-Gómez JC (1994) Taxonomic and ecological remarks on boring sponges (Clionidae) from the Straits of Gibraltar (southern Spain): tentative bioindicators? Zool J Linn Soc 112:407-424

Carballo JL, Naranjo SA, García-Gómez JC (1996) Use of marine sponges as stress indicators in marine ecosystems at Algeciras Bay (Southern Iberian Peninsula). Mar Ecol Prog Ser 135:109_ 122

Clarke KR, Green RH (1988) Statistical design and analysis for a 'biological effects' study. Mar Ecol Prog Ser 46:213-226

Dalfsen JA van, Essink K, Toxvig Madsen H, Birklund J, Romero J, Manzanera M (2000) Differential response of macrozoobenthos to marine sand extraction in the North Sea and the western Mediterranean. ICES J Mar Sci 57:1439-1445

Defeo O (1996) Recruitment variability in sandy beach macroinfauna: much to learn yet. Rev Chil Hist Nat 69:615-630

De Grave S, Whitaker A (1999) Benthic community re-adjustment following dredging of a muddy-maerl matrix. Mar Pollut Bull 38:102-108

De Groot SJ (1996) The physical impact of marine aggregate extraction in the North Sea. ICES J Mar Sci 53:1051-1053

Desprez M (2000) Physical and biological impact of marine aggregate extraction along the French coast of the eastern English Channel: short- and long-term post-dredging restoration. ICES J Mar Sci 57:1428-1438

Estacio FJ, García-Adiego E, Fa D, García-Gómez JC, Daza JL, Hortas F, Gómez-Ariza JL (1997) Ecological analysis in a polluted area of Algeciras Bay (Southern Spain): external vs. 
internal outfalls and environmental implications. Mar Pollut Bull 34:780-793

Ferraro SP, Cole FA (1990) Taxonomic level and sample size sufficient for assessing pollution impacts on the Southern California Bight macrobenthos. Mar Ecol Prog Ser 67:251-262

Ferraro SP, Cole FA (1995) Taxonomic level sufficient for assessing pollution impacts on the Southern California Bight macrobenthos-revisited. Environ Toxicol Chem 14:1031-1040

Guitian F, Carballas J (1976) Técnicas de análisis de suelos. Ed Pico Sacro, Santiago de Compostela

Hall SJ (1994) Physical disturbance and marine communities: life in unconsolidated sediments. Oceanogr Mar Biol Annu Rev 32:179-239

Harvey M, Gauthier D, Munro J (1998) Temporal changes in the composition and abundance of the macro-benthic invertebrate communities at dredged material disposal sites in the Anse à Beaufils, Baie des Chaleurs, eastern Canada. Mar Pollut Bull 36:41-55

Herman PMJ, Heip C (1988) On the use of meiofauna in ecological monitoring: who needs taxonomy? Mar Pollut Bull 19:665-668

Kaiser MJ, Spencer BE (1996) The effects of beam-trawl disturbance on infaunal communities in different habitats. J Anim Ecol 65:348-358

Kenny AJ, Rees HL (1994) The effects of marine gravel extraction on the macrobenthos: early post-dredging recolonisation. Mar Pollut Bull 28:442-447

Kenny AJ, Rees HL (1996) The effects of marine gravel extraction on the macrobenthos: results 2 years postdredging. Mar Poll Bull 32:615-622

Kenny AJ, Rees HL, Greening J, Campbell S (1998) The effects of marine gravel extraction on the macrobenthos at an experimental dredge site off north Norfolk, UK (results 3 years postdredging). ICES CM 1998/V:14:1-8

Legendre P, Legendre L (1998) Numerical ecology. Elsevier, Amsterdam

Lewis FG, Stoner AW (1981) An examination of methods for sampling macrobenthos in sea-grass meadows. Bull Mar Sci 33:296-304

Lewis MA, Weber DE, Stanley RS, Moore JC (2001) Dredging impact on an urbanized Florida bayou: effects on benthos and algal-periphyton. Environ Pollut 115:161-171

López-Jamar E, Mejuto J (1988) Infaunal benthic recolonization after dredging operations in La Coruña Bay, NW Spain. Cah Biol Mar 29:37-49

López-Jamar E, González G, Mejuto J (1986) Temporal changes of community structure and biomass in two subtidal macroinfaunal assemblages in La Coruña bay, NW Spain. Hydrobiologia 142:137-150

López-Jamar E, Francesch O, Dorrío AV, Parra S (1995) Longterm variation of the infaunal benthos of La Coruña Bay (NW Spain): results from a 12-years study (1982-1993). Sci Mar 59:49-61

McCall P (1977) Community patterns and adaptive strategies of the infaunal benthos of Long Island Sound. J Mar Res 35:221-265

Naranjo S, Carballo JL, García-Gómez JC (1996) Effects of environmental stress on ascidian populations in Algeciras Bay (southern Spain). Possible marine bioindicators? Mar Ecol Prog Ser 144:119-131
Newell RC, Seiderer LJ, Hitchcock DR (1998) The impact of dredging works in coastal waters: a review of the sensitivity to disturbance and subsequent recovery of biological resources on the sea bed. Oceanogr Mar Biol Annu Rev 36:127-178

Newell RC, Seiderer LJ, Robinson JE (2001) Animal:sediment relationships in coastal deposits of the eastern English Channel. J Mar Biol Assoc UK 81:1-9

Pagola-Carte S, Urkiaga-Alberdi J, Bustamante M, Saiz-Salinas JI (2001) Concordance degrees in macrozoobenthic monitoring programmes using different sampling methods and taxonomic resolution levels. Mar Pollut Bull 44:63-70

Pranovi F, Giovanardi O, Franceschini G (1998) Recolonization dynamics in areas disturbed by bottom fishing gears. Hydrobiologia 375/376:125-135

Rosenberg R (1977) Effects of dredging operation on estuarine benthic macrofauna. Mar Pollut Bull 8:102-104

Sánchez-Moyano JE, García-Gómez JC (1998) The arthropod community, especially Crustacea, as a bioindicator in Algeciras Bay (Southern, Spain) based on a spatial distribution. J Coast Res 14:1119-1133

Sánchez-Moyano JE, Estacio FJ, García-Adiego EM, GarcíaGómez JC (2000a) The molluscan epifauna of the alga Halopteris scoparia in Southern Spain as a bioindicator of coastal environmental conditions. J Mollusc Stud 66:431-448

Sánchez-Moyano JE, García-Adiego EM, Estacio FJ, GarcíaGómez JC (2000b) Effect of environmental factors on the spatial distribution of the epifauna of the alga Halopteris scoparia in Algeciras Bay, Southern Spain. Aquat Ecol 34:355267

Sánchez-Moyano JE, García-Adiego EM, Estacio FJ, GarcíaGómez JC (2002) Effect of environmental factors on the spatial variation of the epifaunal polychaetes of the alga Halopteris scoparia in Algeciras Bay (Strait of Gibraltar). Hydrobiologia 470:133-148

Sardá R, Pinedo S, Gremare A, Taboada S (2000) Changes in the dynamics of shallow sandy-bottom assemblages due to sand extraction in the Catalan Western Mediterranean Sea. ICES J Mar Sci 57:1446-1453

Shannon CE, Weaver W (1963) The mathematical theory of communication. University of Illinois Press, Urbana, Ill.

Seiderer LJ, Newell RC (1999) Analysis of the relationship between sediment composition and benthic community structure in coastal deposits: implications for marine aggregate dredging. ICES J Mar Sci 56:757-765

Snelgrove PVR, Butman CA (1994) Animal-sediment relationships revisited: cause versus effects. Oceanogr Mar Biol Annu Rev 32:111-177

Thorson G (1966) Some factors influencing the recruitment and establishment of marine benthic communities. Neth J Sea Res 3.267-293

Vanderklift MA, Ward TJ, Jacoby CA (1996) Effect of reducing taxonomic resolution on ordinations to detect pollution-induced gradients in macrobenthic infaunal assemblages. Mar Ecol Prog Ser 136:137-145.

Warwick RM, Clarke KR (1991) A comparison of some methods for analysing changes in benthic community structure. J Mar Biol Assoc UK 71:225-244 